\title{
Managing multifunctional landscapes: local insights from a Pacific Island Country context
}

DOI:

10.1016/j.jenvman.2019.109692

\section{Document Version}

Accepted author manuscript

Link to publication record in Manchester Research Explorer

\section{Citation for published version (APA):}

Duncan, J., Haworth, B. T., Boruff, B., Wales, N., Biggs, E., \& Bruce, E. (2020). Managing multifunctional landscapes: local insights from a Pacific Island Country context. Journal of Environmental Management, 260, [109692]. https://doi.org/10.1016/j.jenvman.2019.109692

\section{Published in:}

Journal of Environmental Management

\section{Citing this paper}

Please note that where the full-text provided on Manchester Research Explorer is the Author Accepted Manuscript or Proof version this may differ from the final Published version. If citing, it is advised that you check and use the publisher's definitive version.

\section{General rights}

Copyright and moral rights for the publications made accessible in the Research Explorer are retained by the authors and/or other copyright owners and it is a condition of accessing publications that users recognise and abide by the legal requirements associated with these rights.

\section{Takedown policy}

If you believe that this document breaches copyright please refer to the University of Manchester's Takedown Procedures [http://man.ac.uk/04Y6Bo] or contact uml.scholarlycommunications@manchester.ac.uk providing relevant details, so we can investigate your claim.

\section{OPEN ACCESS}


Environmental Management

Elsevier Editorial System(tm) for Journal of

\author{
Manuscript Draft
}

Manuscript Number: JEMA-D-18-06123R2

Title: Managing multifunctional landscapes: local insights from a Pacific Island Country context

Article Type: Research Article

Keywords: Multifunctional landscapes, socio-ecological systems, Fiji, Pacific Island Countries, ecosystem services

Corresponding Author: Dr. John Duncan, PhD

Corresponding Author's Institution: University of Western Australia

First Author: John Duncan, PhD

Order of Authors: John Duncan, PhD; Haworth Billy; Bryan Boruff; Nathan Wales; Biggs Eloise; Bruce Eleanor

Abstract: Across Pacific Island Countries, projects and policies are incorporating objectives related to managing landscape multifunctionality to sustain flows of multiple, valued ecosystem services. Strategies to manage natural resources are often not effective, or do not have intended outcomes, if they do not account for local contexts and the varied needs and constraints of stakeholders who rely upon natural resources for their livelihoods. Through fieldwork in Ba, Fiji, local insights were generated concerning the institutional, geographic, and socio-economic factors which determine and challenge i) different stakeholders' ability to access landscape resources, and ii) stakeholders' capacities to benefit from ecosystem services. The following insights were generated from this research which are important for guiding management of landscape multifunctionality. In Ba hierarchical governance systems present barriers to effective management of landscape multifunctionality, and projects or policies with aims to manage landscapes should establish context appropriate multi-scale governance. Such governance systems should facilitate communication and interaction between different stakeholders, build upon community knowledge, and support communities as key actors in landscape management. Consideration of the spatial footprint of landscape resources, stakeholders' different physical and financial capacities, and the institutional structures that mediate access to resources should be central to landscape management and planning. Various climatic stressors affect flows of ecosystem services from the $\mathrm{Ba}$ landscape and people's capacity to access landscape resources; therefore, it is important that management of landscapes also builds resilience to climate stressors. 
1 Managing multifunctional landscapes: local insights from a Pacific Island Country context 2

3 Abstract:

5 Across Pacific Island Countries, projects and policies are incorporating objectives related to managing landscape multifunctionality to sustain flows of multiple, valued ecosystem services.

Strategies to manage natural resources are often not effective, or do not have intended outcomes, if they do not account for local contexts and the varied needs and constraints of stakeholders who rely upon natural resources for their livelihoods. Through fieldwork in Ba, Fiji, local insights were generated concerning the institutional, geographic, and socio-economic factors which determine and challenge i) different stakeholders' ability to access landscape resources, and ii) stakeholders' capacities to benefit from ecosystem services. The following insights were generated from this research which are important for guiding management of landscape multifunctionality. In Ba hierarchical governance systems present barriers to effective management of landscape multifunctionality, and projects or policies with aims to manage landscapes should establish context appropriate multi-scale governance. Such governance systems should facilitate communication and interaction between different stakeholders, build upon community knowledge, and support communities as key actors in landscape management. Consideration of the spatial footprint of landscape resources, stakeholders' different physical and financial capacities, and the institutional structures that mediate access to resources should be central to landscape management and planning. Various climatic stressors affect flows of ecosystem services from the Ba landscape and people's capacity to access landscape resources; therefore, it is important that management of landscapes also builds resilience to climate stressors.

Keywords: Multifunctional landscapes, socio-ecological systems, Fiji, Pacific islands, ecosystem services

\section{Introduction}

The functioning of societies and economies depends upon the flow of services from landscapes and their constituent ecosystems (Biggs et al., 2015; Carpenter et al., 2009; MEA, 2005). However, mismanagement of environmental resources has negative impacts on ecosystems and their capacity to supply valued services (Foley et al., 2011). Awareness of these negative impacts, and concerns about whether ecosystems will continue to provide the array of services that society desires, has led 
to a shift in focus towards managing landscape multifunctionality as opposed to productionorientated management that seeks to maximise single objectives such as crop yield or profit (O’Farrell and Anderson, 2010; Sayer et al., 2013).

A multifunctional view considers landscapes as 'spatial human-ecological systems that deliver a wide range of functions that can be valued by humans because of economic, sociocultural, and ecological reasons' (Termorshuizen and Opdam (2009); p. 1041). O'Farrell and Anderson (2010) define multifunctional landscapes as 'landscapes created and managed to integrate human production and landscape use into the ecological fabric of a landscape maintaining critical ecosystem function, service flows, and biodiversity retention' (p. 59). Multifunctional landscapes have also been associated with increased climate resilience and mitigation of climate change (Harvey et al., 2014; Scherr et al., 2012) and conservation and biodiversity preservation (Scherr and McNeely, 2008).

The benefits of managing and protecting multifunctional landscapes are applicable to a range of contexts spanning developing and developed countries. Pacific Island Countries represent one region where ecosystem service flows are under threat yet the benefits of preserving landscapes that deliver multiple services would be invaluable. Across Pacific Island Countries livelihoods are supported by a myriad of ecosystem services including food and income from fishing, crops and fruit trees, timber, and livestock (Dacks et al., 2018; Lisson et al., 2016; Taylor et al., 2016; Vunisea, 2016); energy from hydropower and forests (firewood) (Department of Energy, 2013); cultural attachment to the land (Neef et al., 2018); natural hazard regulation and sediment control from forests (Atkinson et al., 2016; Daigneault et al., 2016); and income from tourists attracted to leisure opportunities and landscape aesthetics. In this paper, a multifunctional landscape refers to both seascapes and terrestrial landscapes recognising the interconnection between coastal and terrestrial socioecological systems. Across the Pacific, flows of ecosystem services are under threat due to degradation and mismanagement of natural resources (Sisifia et al., 2016; Wairiu, 2017). There are examples of how landscape (mis)management decisions reduce multifunctionality, which, in turn, has adverse societal impacts; for example, deforestation reducing natural hazard regulation services with subsequent amplified flood impacts in northern Fiji (Daigneault et al., 2016).

In recognising the societal benefits that are provided by ecosystem service flows, government policy and development projects in Pacific Island Countries are increasingly incorporating objectives to manage and enhance landscape multifunctionality. For example, the GEF funded Pacific Ridge to 
services (provisioning, regulating, supporting and cultural) through integrated approaches to land, water, forest, biodiversity and coastal resource management that contribute to poverty reduction, sustainable livelihoods and climate resilience' (Pacific R2R - Ridge to Reef, 2018). The Secretariat of the Pacific Regional Environment Programme (SPREP) is implementing the Pacific Ecosystems-based Adaptation to Climate Change Project in Fiji, Vanuatu, and Solomon Islands (SPREP, 2018). The Fiji 2020 Agricultural Sector Policy Agenda recognises the importance of a diversified agricultural system and also outlines the importance of agroforestry while Fiji's National Climate Change Policy acknowledges traditional crop diversity as a source of resilience (Government of the Republic of Fiji, 2012). Diverse agricultural and cropping systems have been associated with increased climate resilience, resilience of ecosystem service flows, improved ecosystem functioning, and increased benefits to livelihoods (Di Falco et al., 2010; Di Falco and Chavas, 2008; Sibhatu et al., 2015; Thornton and Herrero, 2015) ${ }^{1}$.

Landscape multifunctionality has become prominent in guiding policy used to manage landscapes (Sayer et al., 2013). However, the literature evaluating what enables and inhibits managing landscape multifunctionality in different contexts remains relatively limited (Sayer et al., 2016) echoing the earlier concerns of Carpenter et al. (2009) about the limited evaluation of projects that focus on managing ecosystems for human well-being. This paucity of evaluation is particularly evident in the Pacific Island Countries. In a pan-tropical review of landscape approaches Reed et al. (2017) found only six peer-reviewed studies providing reliable data to evaluate the effect of landscape management on environmental or societal outcomes. Other studies focused on Africa, Latin America and the Caribbean, and South Asia have identified broad patterns in how integrated landscape projects are applied (Estrada-Carmona et al., 2014; Milder et al., 2014; Zanzanaini et al., 2017). However, their focus was not on generating local insights into factors that shape how landscape resources are accessed or determine the ability of stakeholders to benefit from ecosystem services.

Local insights into the institutional, geographic, and socio-economic factors which determine access to landscape resources are important for understanding how society benefits from ecosystem services (Carpenter et al., 2009; Dawson and Martin, 2015; Malmborg et al., 2018; Potschin and Haines-Young, 2013), and, thus, for guiding initiatives seeking to manage landscape multifunctionality. There is a history of failure in natural resource management projects which overlook local heterogeneity in society-environment interactions and the institutional arrangements

\footnotetext{
${ }^{1}$ We refer the reader to Table 5 which outlines several examples of how landscape users in Ba, Fiji, utilise farm and landscape diversity to respond to climatic stressors.
} 
governing these interactions (Leach et al., 1999; Reed et al., 2009). Context specific interactions between people, their local environment, and broader institutional, economic, and environmental changes shape the trajectory of socio-ecological system functioning and service supply (Enfors, 2013). Successful management of landscapes, that deliver multiple ecosystem services to stakeholders, appears contingent on a granular level understanding of a landscape's constituent socio-ecological systems. Such a contextual understanding will be particularly important in Pacific Island Countries due to the local heterogeneity within socio-ecological systems and the diversity and complexity of arrangements governing access to resources (Sisifia et al., 2016).

Given the importance of local understanding to guide effective management of multifunctional landscapes (Carpenter et al., 2009; Potschin and Haines-Young, 2013), this paper draws upon participatory fieldwork in Northern Viti Levu, Fiji (Fig. 1), generating detailed information on how people interact with the landscape to utilise flows of ecosystem services to support livelihoods. The following questions were addressed through this fieldwork: i) What ecosystem services do people derive from the landscape to support their livelihoods, and what pressures influence the availability of these services?, ii) how do people access landscape resources, and what are the barriers to access?, and iii) how do community members obtain information to guide decision making for landscape management? Through addressing these questions we identify and synthesise key concepts derived from a community perspective that can guide initiatives attempting to manage landscape multifunctionality.

\section{Methods and study site}

\subsection{Study Site: Ba River Catchment}

The Ba River in Northern Viti Levu, Fiji, courses through a catchment of mixed land use marked by both commercial and subsistence agriculture (Fig. 1). Ba province has 247,708 residents as identified by the 2017 Census (Fiji Bureau of Statistics, 2018). The population consists of indigenous Fijians (iTaukei Fijians) and people of Indian heritage. The average climate for the Ba landscape is depicted in Fig. 2. The catchment frequently experiences climatic hazards including floods in 2012 (Brown et al., 2014; Daigneault et al., 2016), Tropical Cyclone Winston in 2016 (DFAT, 2017), several recent tropical storms, episodes of drought, and intra-seasonal climatic variability that can bring periods of warm temperatures. 
Fieldwork was conducted primarily with indigenous (iTaukei) Fijians within the settlements of

137 Etatoko and Koronubu-Vunibaka and in the village of Nawaqarua; all three communities are situated

138 in close proximity to households of Fijians of Indian heritage and lie within the mid to lower reaches

139 of the Ba River catchment (Fig. 1). Study communities were selected based on existing relationships

140 and recommendations from the Ba Provincial Conservation Office concerning our research needs,

141 the current situation in the communities, and potential benefits of the research to communities and local stakeholders.

Typically, within indigenous Fijian communities the yavusa is the largest and most inclusive social grouping. Households within a yavusa are sub-divided into land-owning units (mataqali), and mataqali are sub-divided into groups of families termed itokatoka (Fig. 3; please see Walter (1978), Sano (2008), and Lasaqa (1984) for a more detailed discussion of Fijian social groupings). A village chief or yavusa leader presides over the mataqali in a village. Registered indigenous Fijian villages also have a turaga-ni-koro (headman) who interacts with the local formal government structures (Sano, 2008). In settlements that are not registered villages, an appointed advisor plays a similar role to the turaga-ni-koro. Nawaqarua is flanked by the Ba River on the east with croplands and mangrove forests bordering the northern and western sides of the village. Etatoko is approximately six kilometres inland from Nawaqarua. As a result of river bank erosion and severe flooding in 2012, the Etatoko community relocated from its riverine location at Wavuwavu. At the time of fieldwork, Etatoko was not formally registered as a village. Nawaqarua is a registered village and both Nawaqarua and Etatoko are linked to the larger village of Votua through yavusa and mataqali affliation, and share the same yavusa leaders. Koronubu is an iTaukei settlement approximately $17 \mathrm{~km}$ south-east of the Ba River mouth; we conducted fieldwork in the community of Vunibaka within Koronubu (Koronubu-Vunibaka) which is part of mataqali Namacuku from Nasolo and Nailaga villages.

\subsection{Data Collection}

In each community we undertook a range of Participatory Rural Appraisal (PRA) activities:

167 Fieldwork activities collected detailed information on how people interact with the landscape to utilise flows of ecosystem services to support livelihoods. From this information we identified challenges that landscape users experienced when managing landscape resources. 
171 The field activities employed in this research have been used in other rural landscapes to capture

172 how people utilise ecosystem service flows (Malmborg et al., 2018; Sinare et al., 2016). PRA

173 techniques, such as the ones used in this research, emphasise the value of local knowledge and the

174 importance of participants' perspectives (Chambers, 1994). These data generation approaches are

175 suited to capturing information from multiple perspectives, at multiple scales, and integrating socio-

176 economic, biophysical, and climate information (Mwongera et al., 2017). This is important in

177 landscapes such as Ba where there are multiple landscape users and a diversity of landscape resources. Through adopting a methodological pluralism we i) were able to build a more nuanced analysis of human-environment interactions (Rasmussen et al., 2016), and ii) triangulate recurrent themes emerging from data generation using information collected in different fieldwork activities (Schreckenberg et al., 2016). A detailed description of our fieldwork activities is presented in Table 1.

All PRA activities were undertaken separately with male and female community members given that they utilise the landscape in different ways. This allowed for further analytical insights through comparison of experiences. The transect walks and participatory mapping exercises were used to elucidate spatial patterns of landscape users' interactions with landscape resources, which ecosystem services they benefit from, and challenges faced in accessing landscape resources and benefiting from ecosystem service flows. High-resolution satellite imagery was used as a visual aid for the participatory mapping. There were between five and ten participants at each mapping session and one session held with male and female landscape users per community. The route for transect walks were identified to capture the main features discussed in the participatory mapping; the transect walk was led by members of the community with additional community members engaged at various points during the walk. Data were collected on a tablet using the mappt app (https://www.mappt.com.au/) with photos, notes, and a GPS location stored as a .kml file.

Following the participatory mapping and transect walks focus group sessions were held to allow for open and in-depth discussion of key issues related to accessing landscape resources, sourcing information, and learning processes that inform landscape decision making. Large paper sheets with prompting questions written on them were placed in the centre of the discussion, and when necessary, were used to encourage flow of conversation and to keep the topics consistent across communities. These prompting questions were initially developed following discussions with senior community members when arranging the fieldwork. Following preliminary data analysis, we revisited the communities to clarify outstanding issues and validate initial themes that emerged 
to and use of information.

207 All fieldwork activities were undertaken by research assistants fluent in the local language and versed in local customs. A female research assistant conducted all PRA activities with female community members. At the end of each PRA activity the field team debriefed, compared notes for consistency, and identified further points for clarification. All information from the PRA activities were collated in a database for further analysis; this included notes from the transect walks, notes and quotes from focus group discussions, annotations from participatory maps, and open responses to questions posed in the revisit interviews. Information was entered as individual text fragments

214 (e.g. notes associated with a location and photo collected during the transect walk) with associated metadata indicating community, fieldwork activity, and gender of participants. Arrangements for all

Table 1. Overview of participatory rural appraisal (PRA) methods.

\begin{tabular}{|c|c|c|c|c|}
\hline & Participatory Mapping & Focus Group Discussions & Transect Walks & Revisit Interviews \\
\hline Purpose & $\begin{array}{l}\text { - Elucidate what } \\
\text { landscape resources } \\
\text { community members } \\
\text { use to sustain their } \\
\text { livelihoods } \\
\text { - Identify what factors } \\
\text { enable or constrain } \\
\text { access to resources }\end{array}$ & $\begin{array}{l}\text { - Understand decision } \\
\text { making process } \\
\text { regarding use of } \\
\text { landscape resources } \\
\text { - Identify where } \\
\text { community members } \\
\text { source information to } \\
\text { guide decision making } \\
\text { - Identify barriers to } \\
\text { accessing information } \\
\text { - Discussion on access } \\
\text { and utilisation of } \\
\text { climate information }\end{array}$ & $\begin{array}{l}\text { - Capture landscape } \\
\text { resources the } \\
\text { community identified } \\
\text { as important to their } \\
\text { livelihoods } \\
\text { - Capture individual } \\
\text { perspectives to } \\
\text { complement } \\
\text { aggregated } \\
\text { community } \\
\text { perspectives } \\
\text { - Use landscape } \\
\text { resource units as } \\
\text { prompts and } \\
\text { stimulants for } \\
\text { discussion }\end{array}$ & $\begin{array}{l}\text { - Conducted after } \\
\text { first round of } \\
\text { analysis of } \\
\text { information } \\
\text { collected in } \\
\text { participatory } \\
\text { mapping (PM), } \\
\text { focus group } \\
\text { discussions, and } \\
\text { transect walks } \\
\text { Clarification of } \\
\text { outstanding issues } \\
\text { - Validation of key } \\
\text { themes }\end{array}$ \\
\hline Method & $\begin{array}{l}\text { - 'Hands-on mapping' } \\
\text { (Corbett, 2009) with } \\
\text { community members } \\
\text { assisted by local } \\
\text { research assistant } \\
\text { - Landscape resources } \\
\text { sketch-mapped on } \\
\text { paper with fine } \\
\text { spatial resolution } \\
\text { satellite imagery } \\
\text { used as a tool for } \\
\text { orientation } \\
\text { - Discussion regarding } \\
\text { use, challenges with } \\
\text { availability, barriers } \\
\text { to access, and }\end{array}$ & $\begin{array}{l}\text { - Open discussion } \\
\text { informed by the } \\
\text { outcomes of the } \\
\text { preceding PM activity } \\
\text { facilitated by local } \\
\text { research assistants } \\
\text { - Discussion prompts } \\
\text { developed to aid } \\
\text { facilitators and ensure } \\
\text { the discussion } \\
\text { remained focused } \\
\text { Discussion prompts } \\
\text { were updated after } \\
\text { each focus group } \\
\text { session to allow further } \\
\text { exploration of issues }\end{array}$ & $\begin{array}{l}\text { - The initial route for } \\
\text { the transect walk was } \\
\text { discussed following } \\
\text { the PM activity } \\
\text { - Photographs and } \\
\text { notes collected at } \\
\text { each landscape } \\
\text { resource unit using } \\
\text { mobile Geographic } \\
\text { Information Systems } \\
\text { (GIS) mapping app } \\
\text { Mappt on tablets } \\
\text { - High-spatial } \\
\text { resolution imagery } \\
\text { from Google Maps } \\
\text { used as an ancillary }\end{array}$ & $\begin{array}{l}\text { - Structured } \\
\text { discussion with } \\
\text { community leader } \\
\text { and other } \\
\text { community } \\
\text { members } \\
\text { - Local research } \\
\text { assistant asked a } \\
\text { set of open, pre- } \\
\text { specified } \\
\text { questions }\end{array}$ \\
\hline
\end{tabular}




\begin{tabular}{|c|c|c|c|c|}
\hline & $\begin{array}{l}\text { climate impacts and } \\
\text { response for mapped } \\
\text { resources }\end{array}$ & $\begin{array}{l}\text { that arose in previous } \\
\text { sessions }\end{array}$ & $\begin{array}{l}\text { support for the } \\
\text { transect walk and } \\
\text { discussions }\end{array}$ & \\
\hline Participants & $\begin{array}{l}\text { - Between five and } 10 \\
\text { participants } \\
\text { - Separate mapping } \\
\text { sessions for male and } \\
\text { female participants }\end{array}$ & $\begin{array}{l}\text { - Same participants as } \\
\text { for participatory } \\
\text { mapping }\end{array}$ & $\begin{array}{l}\text { - Transect walk } \\
\text { conducted separately } \\
\text { with female and male } \\
\text { community members } \\
\text { - One or two } \\
\text { community members } \\
\text { acted as guides } \\
\text { through the walk } \\
\text { - Discussions at each } \\
\text { landscape resource } \\
\text { unit with the } \\
\text { resource user and } \\
\text { guides }\end{array}$ & $\begin{array}{l}\text { - Community leader } \\
\text { (in Koronubu- } \\
\text { Vunibaka the male } \\
\text { community elder } \\
\text { was not present } \\
\text { due to cultural } \\
\text { commitments so } \\
\text { the revisit } \\
\text { interview was } \\
\text { conducted with a } \\
\text { senior female } \\
\text { community } \\
\text { member) } \\
\text { Three to four } \\
\text { other community } \\
\text { members were } \\
\text { present }\end{array}$ \\
\hline
\end{tabular}

221

222

223

224

225

\subsection{Data Analysis}

The data from the PRA activities were analysed using qualitative data analysis techniques (Gibbs, 2008). Initially the text fragments from the different fieldwork activities were organised into categories related to availability of ecosystem services, accessing landscape resources, and accessing and using information. Text fragments were also assigned codes related to a particular landscape resource (e.g. mangroves, fields near homes), the participants who provided the data (e.g. female transect walks), and the research activity (e.g. participatory mapping). This was to facilitate easy sorting and re-organising of the data for analysis. Subsequently, for each research question, a process of iterative thematic coding was undertaken to identify key explanatory themes in the data. These themes were refined through re-evaluation of the existing data and review of ancillary information including policy documents and interviews undertaken with secondary stakeholders (e.g. staff working at the national level in Government, development agencies, and the private sector). This process ensured our findings were grounded in the original data and served as pseudovalidation of the key themes we identified. The key themes for each research question are presented in the results section alongside examples from the data.

The coding was primarily undertaken by one researcher; however, an initial section of the data was jointly coded by two researchers to develop a coherent coding process. Subsequently, at regular stages in the coding process, random subsets of the data were extracted and re-coded by a second researcher to ensure consistency. This multiple-coding strategy (Barbour, 2001) was important to 


\section{Results}

\subsection{Availability of ecosystem services}

250

251 A summary of how the landscape is utilised by the community members is presented in Table 2. It was typical for households to directly benefit from multiple streams of ecosystem services and to generate income through the sale of produce derived from the landscape. Many households also generated income through remittances or through household members working in a range of nonnatural resource related professions.

Table 2. Profiles of the three communities in Ba Catchment where fieldwork was conducted (accurate at the time of fieldwork).

\begin{tabular}{|c|c|c|c|}
\hline & Nawaqarua & Etatoko & Koronubu-Vunibaka \\
\hline $\begin{array}{l}\text { Community } \\
\text { Governance }\end{array}$ & $\begin{array}{l}\text { - Turaga-ni-koro } \\
\text { - Yavusa leaders based in } \\
\text { another village }\end{array}$ & $\begin{array}{l}\text { - Turaga-ni-koro based in } \\
\text { Votua village } \\
\text { - Yavusa leaders based in } \\
\text { another village } \\
\text { - Decisions at the settlement } \\
\text { made by community elder } \\
\text { but he is subservient to } \\
\text { community leaders in } \\
\text { Votua }\end{array}$ & $\begin{array}{l}\text { - Turaga-ni-koro based in } \\
\text { Nasolo village } \\
\text { - Yavusa leaders based in } \\
\text { Nasolo village (near Ba Town } \\
\text { and \$17 (FJD) carrier ride } \\
\text { away) } \\
\text { - Koronubu has an advisor to } \\
\text { represent the entire } \\
\text { settlement }\end{array}$ \\
\hline Village Profile & $\begin{array}{l}\text { - } 56 \text { households } \\
\text { - All households have piped } \\
\text { water (but difficulties in } \\
\text { paying water bills) } \\
\text { - } 20 \text { households do not have } \\
\text { electricity } \\
\text { - Good mobile phone signal } \\
\text { - Not all households have a TV } \\
\text { - One computer } \\
\text { - Internet access through } \\
\text { mobile phone data }\end{array}$ & $\begin{array}{l}\text { - } 16 \text { households } \\
\text { - No households have piped } \\
\text { water but all households } \\
\text { have access to water from } \\
\text { a borewell (solar operated } \\
\text { pump) } \\
\text { - No households have mains } \\
\text { electricity } \\
\text { - Seven households use solar } \\
\text { power and nine } \\
\text { households use kerosene } \\
\text { lanterns or battery lamps } \\
\text { - Good mobile phone signal } \\
\text { - One TV (household has a } \\
1000 \text { kw solar panel) }\end{array}$ & $\begin{array}{l}\text { - } 16 \text { households } \\
\text { - } 14 \text { households have piped } \\
\text { water } \\
\text { - No households have mains } \\
\text { electricity } \\
\text { - Two households use kerosene } \\
\text { lanterns, two households use } \\
\text { diesel generators, the rest use } \\
\text { solar panels and battery lamps } \\
\text { - Irregular mobile phone signal } \\
\text { - Two households have a } \\
\text { television }\end{array}$ \\
\hline $\begin{array}{l}\text { Landscape } \\
\text { Resources and } \\
\text { Services }\end{array}$ & $\begin{array}{l}\text { - Fishing in the ocean and } \\
\text { reefs } \\
\text { - Fishing in Ba river } \\
\text { - Collect crabs from } \\
\text { mangroves } \\
\text { - Collect freshwater mussels } \\
\text { from Ba river } \\
\text { - Farming vegetables in plots } \\
\text { near homestead } \\
\text { - Cassava and root crops in }\end{array}$ & $\begin{array}{l}\text { - Fishing in the Ba river and } \\
\text { small creeks } \\
\text { - Farming root crops, } \\
\text { vegetables, and fruit trees } \\
\text { at Wavuwavu } \\
\text { - Extraction of firewood } \\
\text { from Wavuwavu } \\
\text { - Farming root crops (mainly } \\
\text { cassava), vegetables, and } \\
\text { fruit trees at Etatoko }\end{array}$ & $\begin{array}{l}\text { - Fishing in the Ba river and } \\
\text { small creeks } \\
\text { - Farming root crops, } \\
\text { vegetables, and fruit trees in } \\
\text { plots surrounding settlement } \\
\text { - Farming vegetables and fruit } \\
\text { trees in plots near homestead }\end{array}$ \\
\hline
\end{tabular}




\begin{tabular}{|c|c|c|c|}
\hline & $\begin{array}{l}\text { fields surrounding the village } \\
\text { - Fruit trees } \\
\text { - Firewood from mangroves }\end{array}$ & $\begin{array}{l}\text { - Farming vegetables and } \\
\text { fruit trees in plots near } \\
\text { homestead }\end{array}$ & \\
\hline
\end{tabular}

260

261

There were some commonalities in the spatial patterns and socially differentiated nature of resource use across the communities. For example, women often had a greater responsibility for cultivating vegetables in plots close to the homestead. However, there was diversity in landscape resource use between and within communities. One clear distinction was the predominance of fishing and marine life extraction from mangroves and fishing grounds in Nawaqarua compared to the predominance of subsistence farming in Koronubu-Vunibaka. Within communities, households operated plots of land with varied quality and exposures to climatic stressors and undertook a range of activities within the landscape. For example, in Koronubu-Vunibaka households with paper mulberry (Broussonetia papyrifera) trees were able to sell bark for making masi cloth and benefit from this income stream. Similarly, in Etatoko women with pandanus trees were able to weave mats and generate income for the household; this extra income was apparent in greater levels of household assets.

The results also revealed that community members faced multiple challenges in benefiting from ecosystem service flows from landscape resources (Table 3). Some of the challenges listed in Table 3 are symptomatic of a lack of wealth and assets; for example, a lack of boat access for fishing, tools for farming, or reliance on solar power in lieu of mains electricity during inclement weather. Other challenges were related to activities occurring in distant locations but with local impacts such as the release of chemicals from sugar mills upstream reducing downstream fish stocks, flood debris from upstream washed onto downstream fields, or upstream deforestation amplifying flood impacts downstream. The geographic relationship between people and resources in the landscape created challenges; for example, women from Nawaqarua reported that it was time consuming to walk to mangroves to collect crabs. Climatic variation and natural hazards affected flows of ecosystem services and people's capacity to utilise landscape resources (Table 3). The institutional arrangements that govern people's interaction with the landscape also presented indirect challenges 
Table 3. Challenges to the availability of ecosystem services in the Ba landscape for female $q$ and

\begin{tabular}{|c|c|c|c|}
\hline $\begin{array}{l}\text { Landscape } \\
\text { Resource }\end{array}$ & $\begin{array}{l}\text { Landscape } \\
\text { Users }\end{array}$ & Challenge & Example(s) \\
\hline \multirow[t]{9}{*}{$\begin{array}{l}\text { Fields (away } \\
\text { from home) }\end{array}$} & \multirow{7}{*}{$\sigma_{f a}^{\pi}$} & climatic variation & $\begin{array}{l}\text { small creeks flood fields in heavy rains; warmer } \\
\text { temperatures impact crops }\end{array}$ \\
\hline & & theft & $\begin{array}{l}\text { people stealing crops forcing farmer to change planting } \\
\text { location }\end{array}$ \\
\hline & & low wages & $\begin{array}{l}\text { farmers that cannot afford to go fishing get lower wages for } \\
\text { clearing sugarcane fields }\end{array}$ \\
\hline & & natural hazards & $\begin{array}{l}\text { flooding of sugarcane fields reduces demand for labour and } \\
\text { subsequent income; flooding of fields; flood debris, weeds, } \\
\text { and invasive trees washed onto fields; cyclone damage to } \\
\text { crops }\end{array}$ \\
\hline & & lack of assets & lack tools and seeds for farming \\
\hline & & erosion & river bank erosion washing away fields \\
\hline & & land quality & $\begin{array}{l}\text { local variations in land quality / fertility; saline land close to } \\
\text { the coast which cannot be cultivated }\end{array}$ \\
\hline & \multirow{2}{*}{$\mathcal{P}_{\mathrm{fa}}$} & erosion & river bank erosion washing away fields \\
\hline & & land quality & $\begin{array}{l}\text { land close to the road is not fertile with thin layer of soil } \\
\text { before soft stones - soil closer to river is more fertile; } \\
\text { concern that other farmers grazing cattle will impact land } \\
\text { quality }\end{array}$ \\
\hline \multirow{11}{*}{$\begin{array}{l}\text { Fields (near } \\
\text { home/kitchen } \\
\text { garden) }\end{array}$} & \multirow{5}{*}{$\sigma_{f a}$} & natural hazards & flooding of fields; cyclone damage \\
\hline & & pests & insects eating vegetables \\
\hline & & land quality & $\begin{array}{l}\text { limited fertile land and stones in soil make it hard to farm } \\
\text { some areas during drought }\end{array}$ \\
\hline & & lack of assets & lack tools and seeds for farming \\
\hline & & climatic variation & drought; warm temperatures impact crops \\
\hline & \multirow{6}{*}{$\Upsilon_{f a}$} & land quality & not planting vegetables because of sandy soil \\
\hline & & lack of assets & $\begin{array}{l}\text { lack of tools to make masi from paper mulberry tree; taps / } \\
\text { piped water required for irrigation during dry spells }\end{array}$ \\
\hline & & climatic variation & drought; warm temperatures impact crops \\
\hline & & theft & theft of vegetables \\
\hline & & climate change & $\begin{array}{l}\text { weather is more unpredictable and crops that used to grow } \\
\text { well do not anymore; elderly farmers perceive more flooding }\end{array}$ \\
\hline & & natural hazards & $\begin{array}{l}\text { strong winds / heavy rain push over paper mulberry trees; } \\
\text { flooding of fields; cyclone damage }\end{array}$ \\
\hline \multirow[t]{5}{*}{ Ocean } & \multirow[t]{5}{*}{$\sigma_{f i}^{\top}$} & decline in stocks & $\begin{array}{l}\text { declining fish stocks in fishing grounds; lots of fishing vessels } \\
\text { have licenses to fish on community fishing grounds lowering } \\
\text { stocks }\end{array}$ \\
\hline & & dynamite fishing & dynamite fishing kills all the fish including young fish \\
\hline & & lack of assets & limited availability of boats for fishing \\
\hline & & natural hazards & $\begin{array}{l}\text { floodwater and storms prevent fishing; floodwater can } \\
\text { reduce fish catch in fishing grounds }\end{array}$ \\
\hline & & price of fuel & price of fuel for fishing boats is expensive \\
\hline \multirow[t]{2}{*}{ River } & \multirow{2}{*}{$q_{g}$} & decline in stocks & decline in freshwater mussel stocks in Ba River \\
\hline & & time constraints & $\begin{array}{l}\text { time constraints to collect freshwater mussels as a single } \\
\text { parent }\end{array}$ \\
\hline
\end{tabular}




\begin{tabular}{|c|c|c|}
\hline & natural hazards & $\begin{array}{l}\text { cyclone washed away freshwater mussels; strong currents } \\
\text { and floodwater make collecting mussels dangerous }\end{array}$ \\
\hline & $\begin{array}{l}\text { sugarcane processing } \\
\text { chemical release }\end{array}$ & $\begin{array}{l}\text { chemicals released from the sugarcane mill into Ba river } \\
\text { reduce fish catch }\end{array}$ \\
\hline & natural hazards / erosion & $\begin{array}{l}\text { debris from upstream and bank erosion making areas which } \\
\text { used to be good for fishing too shallow }\end{array}$ \\
\hline \multirow[t]{6}{*}{ Mangrove } & time constraints & time constraints to collect crabs as a single parent \\
\hline & natural hazards & $\begin{array}{l}\text { during heavy rain cannot collect mud crabs or sell them at } \\
\text { markets; cyclones damage mangroves }\end{array}$ \\
\hline & climatic variation & continuous rain can make collecting crabs difficult \\
\hline & proximity & long walk from homes to collect crabs \\
\hline & $\begin{array}{l}\text { overharvesting marine } \\
\text { life }\end{array}$ & $\begin{array}{l}\text { more women collecting crabs resulting in smaller crab } \\
\text { catches }\end{array}$ \\
\hline & dredging & $\begin{array}{l}\text { loss of mangrove trees due to dumping of dredging spoils; } \\
\text { kills habitat for marine life }\end{array}$ \\
\hline \multirow{5}{*}{$\begin{array}{l}\text { Other } \\
\text { locations }\end{array}$} & climate change & perceived change in tree species due to climate change \\
\hline & proximity to firewood & limited firewood near homes \\
\hline & $\begin{array}{l}\text { climatic variation / } \\
\text { natural hazards }\end{array}$ & solar power does not work in bad weather \\
\hline & $\begin{array}{l}\text { wild animals killing } \\
\text { livestock }\end{array}$ & mongoose killing chickens near home \\
\hline & $\begin{array}{l}\text { climatic variation / } \\
\text { natural hazards }\end{array}$ & solar power does not work in bad weather \\
\hline
\end{tabular}

292

293

294

295

296

297

298

299

300

301

302

303

304

305

306

307

308

309

310

\subsection{Access to landscape resources}

Access to landscape resources is important for undertaking activities that generate ecosystem services. In Fiji, land access is typically governed by three types of land ownership or leases: native (iTaukei) land, crown land, and freehold land (Department of Town and Country Planning, 2017). Native land is owned by iTaukei villages and access to this land is determined by mataqali affiliation or through leases administered by the iTaukai Land Boards Trust (TLTB) on behalf of the traditional land owners. In this research, sugarcane plantations surround all three communities on land typically leased from the iTaukei landowners. Reefs near the coastal villages are designated as village fishing grounds; the village at Nawaqarua has access to the traditional fishing grounds of Votua.

People faced a range of challenges to accessing landscape resources; these are listed in Table 4 under categories of institutional, capacity (e.g. related to finance, assets, and infrastructure), and geographic factors. The spatial arrangement of resources within the landscape affects different groups' ability to capture ecosystem services; for example, women in Nawaqarua highlighted the burden of long walks to collect crabs from mangroves and strong river currents challenging collection of freshwater mussels (Table 4). A lack of financial capacity, assets, or infrastructure can 
restrict access to landscape resources; for example, money to purchase a spot on boats was required

312 to access offshore fishing grounds. In Etatoko, farmers lacked tools to clear trees and debris washed

313 onto their fields during floods; this resulted in reduced access to land for farming. Physical capacity,

314 as well as financial capacity, intersected with the spatial location of landscape resources to influence

315 resource accessibility; elderly farmers reported that it was challenging to cultivate plots far from

316 their home (Table 4).

A range of institutional factors influence resource access; in particular, the nature of land ownership and leasing of iTaukei land is important in determining land access. The reality of this arrangement presented several challenges to community members seeking to utilise landscape resources to support livelihoods. There was an instance where the TLTB had renewed leases on iTaukei land without undertaking prior consultation with the land owners in Koronubu-Vunibaka. The land owners did not want to renew the lease and wished to cultivate the land themselves. The experience of Etatoko's inhabitant's relocation illustrates how the land tenure arrangements can impede flexibility in accessing and managing landscape resources. The community at Etatoko relocated their settlement to the current site from a riverine location that suffered bank erosion and frequent flooding. However, this move was to land traditionally owned by a different mataqali and brought the community into conflict with the village leadership (Table 4). Institutional arrangements within communities, that are often informal, also challenge people's ability to access landscape resources (Table 4). For example, elderly village members restricted the expansion of one farmer's area of cultivation due to envy over his productivity even though space was available. There were also cases where there was limited regulation of access to landscape resources. Community members highlighted concerns over limited regulation of mangrove use, limited regulation of use of fishing grounds, and in the process of provision of licenses for fishing (Table 4).

Table 4. Challenges faced by community members in Etatoko, Nawaqarua, and Koronubi-Vunibaka in accessing different landscape resources.

\begin{tabular}{ll}
\hline Factor & Challenge \\
\hline Institutional & - Male head of household decides where to plant \\
- Conflict over land ownership when moving settlement (Etatoko) \\
- No control over fishing license approvals \\
- Difficulties in having land access formalised in writing \\
- Community 'elders' preventing farmers from expanding area under cultivation - envy over \\
productivity of some farmers \\
- Community leaders are not strict in regulating village fishing grounds \\
- No regulation of firewood collection from mangroves \\
- Communities not engaged in the process of leasing their traditional land by government \\
organisations \\
\hline Capacity (e.g. & - Cannot work plots away from homestead due to old age \\
financial, physical, & - Debris from flooding covers fields - community members do not have tools to remove it \\
\hline
\end{tabular}




\begin{tabular}{ll}
\hline infrastructure) & - Burn weeds to clear land if 'weedicide' is too expensive \\
- Limited availability and cost of boats for fishing \\
- Cost of fuel for boats for fishing \\
\hline - Cannot work plots away from homestead due to old age \\
- Flooding makes it risky to collect harvests \\
- Flooding causes shift in planting location \\
- Firewood not close to settlements \\
- Long walk for women to mangroves to collect crabs \\
- Strong currents when collecting freshwater mussels \\
- Settlement location far from traditional village where village meetings are held - time and \\
cost to travel to village \\
- Long walk for labouring activities on sugarcane plantations
\end{tabular}

\subsection{Information and decision-making}

\subsubsection{Stakeholder interaction across landscape levels}

Communities interacted with the local government via the turaga-ni-koro or through advisors (in settlements). Both Etatoko and Koronubu-Vunibaka settlements were located away from their traditional villages where the turaga-ni-koro is based. Community members in Koronubu-Vunibaka emphasised the financial costs of travelling to their traditional village to engage with the turaga-nikoro, the yavusa leaders, and for village duties. In Nawaqarua, village meetings were held every month and the turaga-ni-koro discussed village issues at Provincial level meetings.

Typically, community members reported that local agricultural officials ${ }^{2}$ only came to villages after sought assistance from the local agricultural office, and often they do not know when seeds are available at the agricultural office. The turaga-ni-koro in Nawaqarua and Votua were able to call agricultural officers if they needed information or assistance. However, female farmers in not aware of what was discussed and were reluctant to approach agricultural officials as they agricultural officials.

\footnotetext{
${ }^{2}$ When using the term 'local government officials' we refer to employees of government departments or ministries operating at levels above the village or community (i.e. District or Province) but below the National level. There are government offices located at the Province level (Lautoka) and at the District level (Ba) which provide a range of rural development and administrative functions. This includes the Ministry of Agriculture, which through its extension division has technical officers at the District.

${ }^{3}$ One female farmer reported that an agricultural extension officer had given her seeds for beans; however, the seeds were not replaced the following season.
} 
363 The challenges community members faced in interacting with other landscape stakeholders reflects

364 the predominantly hierarchical governance structure within $\mathrm{Ba}$. This structure does not reflect the

365 local heterogeneity in the landscape and means local government officials struggle to support the

366 diversity of landscape users. For example, the modes of government engagement with communities,

367 via interaction with an advisor or turaga-ni-koro do not account for the geographic dispersion of

368 communities within a village unit (e.g. Koronubu-Vunibaka and Etatoko are dislocated from their

369 traditional villages). Further, there were concerns that when community-level issues were raised at

370 the Provincial-level by the turaga-ni-koro they 'fall on deaf ears'. Agricultural extension officers are a

371 main point of contact with the Ministry of Agriculture yet the little community interaction with

372 agricultural officials is through predominantly male-only channels. Further, agricultural officials were

373 perceived, by community members, to have a predominant focus towards larger, more commercial

374 farms. These examples highlight the limitation of using an individual, within a hierarchical

375 governance structure, as a conduit for information between heterogeneous groups. The community-

376 level perception of the agricultural officials' focus and support does not reflect the reality of

377 landscape use and functioning. For example, women are key landscape users and cultivate a

378 diversity of crops and there are many diverse small-scale farms operated by indigenous Fijians.

Provision of information about the importance of protecting fisheries from staff of the University of the South Pacific (USP) and the Department of Fisheries incentivised the yavusa leaders in Votua to initiate a Marine Protected Area on the village's traditional fishing grounds. The staff from USP used videos and discussions to highlight the importance of protecting fishing grounds and warned about the consequences of continued fishing. This illustrates how provision of information to communities can incentivise action to manage landscape (seascape) resources. However, this appeared to be an isolated case rather than common practice in $\mathrm{Ba}$. The norm is for limited sharing of information from

\subsubsection{Intra-community stakeholder interaction}

Knowledge of how to utilise landscape resources is held within communities and generated through past experiences. For example, in Etatoko, based upon a long history of cultivation at Wavuwavu,

393 farmers knew which crops were suited to different seasons. Farmers planted vegetables at the end of the cyclone season in March and village elders had instructed farmers to plant duruka (Saccharum edule) on flood prone land. Similarly, community members in Nawaqarua were able to predict the 
weather 'by looking at the skies', and elders use the stars to navigate when fishing. Elderly women in Nawaqarua teach younger women how to collect crabs from the mangroves. The relocation of the community from Wavuwavu to Etatoko exemplifies the impacts associated with loss of community knowledge. When the community moved to Etatoko they did not know which plots were fertile and what spatial configuration of crops would best support livelihoods and buffer climatic stressors.

\section{Community members expressed a preference for sharing information regarding landscape use} through intra-community, informal, face-to-face interaction. For example, female community members in Nawaqarua mentioned how informal conversation often initiated sharing of vegetable seeds. In Koronubu-Vunibaka, not all households owned a radio, but households with a radio passed on weather forecasts.

In contrast to the informal information exchange between community members that facilitated effective landscape management community members reported some challenges when engaging with the formal community-level governance system. This included accessing information about landscape management that would affect ecosystem service provision; for example, community members in Nawaqarua and Votua felt they were not fully informed about the potential effects of mining operations that are now active in the Ba River delta. A village committee in Votua was managing the mining compensation funds; the community members in Nawaqarua were concerned that no-one from their village was represented on this committee. In addition, a lack of assets inhibits community access to information about landscape resources; for example, the communities at Nawaqarua and Votua reported that they do not have enough boats to monitor their fishing grounds. The formal community-level governance system, at times, did not function in response to community-level concerns about landscape management or needs. The yavusa leaders approved licenses and permission for people, who were not members of the community, to extract fish and coral from fishing grounds without community agreement.

\subsubsection{Information exchange via technology}

Community members received weather forecasts via the radio. If the forecast predicted heavy rain or flooding they would attempt to harvest crops. However, it was mentioned that forecasts came too late to allow farmers to fully prepare. Most community members had access to mobile phones and were receptive to idea of seasonal weather forecasts via text messages. Some women in Nawaqarua subscribed to a weather forecast through their mobile phone provider, and if heavy rain 
430 was forecast they would not go swimming to collect freshwater mussels due to currents. In Etatoko

431 and Koronubu-Vunibaka community members mentioned challenges to accessing information via

432 mobile phones due to a lack of electricity and poor reception in bad weather. It was frequently reported that younger community members had a greater capacity to use mobile phones to access information. In all communities, the cost of mobile phone credit was mentioned as being prohibitive.

\section{Discussion}

Sayer et al. (2013) and Kusters et al. (2017) emphasise that platforms which facilitate communication between stakeholders across spatial levels are important for effective landscape management; Reed et al. (2009) make a similar point in the broader context of sustainable natural resource management. Limited access to information has been shown to inhibit community-level environmental management in Pacific Island Countries (Nunn et al., 2014). Our findings corroborate these assertions; for example, the multi-stakeholder arrangements that enabled communication between community members, academics, and government officials led to a restriction on fishing in Votua and Nawaqarua (section 3.3.1). Experiences from other landscapes also found that removing barriers to stakeholder communication enables change in ecosystem management (Tompkins and Adger, 2004). However, in Ba, the norm is for limited communication between stakeholders across hierarchical levels, with this barrier particularly apparent between communities and other landscape stakeholders. Thus, initiatives in the South Pacific with a focus on landscape multifunctionality should prioritise developing platforms that facilitate cross-level communication between stakeholders.

Natural hazards and climatic variation negatively affect flows of ecosystem services (Table 3 ) and restrict access to landscape resources (Table 4). Thus, successful management of landscapes requires awareness of climatic risk and consideration of landscape design that increases the resilience of ecosystem service flows. Landscape users in Ba exploit the multifunctional nature of the

457 landscape to respond to climatic stressors and stabilise flows of ecosystem services (Table 5). This

458 implies that effective management of landscape multifunctionality can simultaneously increase the

459 climate resilience of ecosystem service flows while meeting other development objectives pursued

460 in rural landscapes (Biggs et al., 2015; Mwongera et al., 2017; Scherr et al., 2012). The myriad ways

461 community members utilise the landscapes in response to change reflects a rich community

462 knowledge base. This knowledge is an asset for informing effective response to environmental 463 challenges within Pacific landscapes (Janif et al., 2016; McMillen et al., 2014). Strategies for 
landscape management under changing climates and dynamic environments in the Pacific could complement and build upon this knowledge. This is another example of why removing barriers to communication across-levels and between stakeholders is important for managing landscape multifunctionality.

Table 5. Examples of use of landscape use in response to climatic stressors. Coping refers to shortterm and reactive responses to variation in weather or 'unexpected' climatic events and adapting refers to more permanent responses to trends in climate or efforts to permanently reduce sensitivity to weather variation.

\begin{tabular}{|c|c|c|}
\hline Coping & Both & Adapting \\
\hline $\begin{array}{l}\text { - Replant crops (often cassava) } \\
\text { affected by drought } \\
\text { - Cover exposed roots of crops after } \\
\text { floods (chili, pandanus trees) } \\
\text { - Moving crops away from exposed } \\
\text { land }{ }^{2} \\
\text { - Crop choice due to weather } \\
\text { warning }{ }^{3} \\
\text { - Collect mud crabs during bad } \\
\text { weather as men cannot go out } \\
\text { fishing with boats } \\
\text { - Diversify livelihood activities (e.g. } \\
\text { sell crabs to buy food as income } \\
\text { from cassava as decreased) }\end{array}$ & $\begin{array}{l}\text { - Hosepipes to water } \\
\text { plants close to } \\
\text { settlement }{ }^{4} \\
\text { - Deliberate crop } \\
\text { diversity }^{5}\end{array}$ & $\begin{array}{l}\text { - Digging a well (for irrigation) } \\
\text { - Dig drainage besides fields } \\
\text { - Moving flood prone vegetables to drier land }{ }^{5} \\
\text { - Vegetables planted under trees to protect } \\
\text { them from weather } \\
\text { - Plant crops at different time-steps to } \\
\text { increase chance of some crops surviving } \\
\text { inclement weather } \\
\text { - Plant different crops in different seasons } \\
\text { - Female farmers think planting more trees } \\
\text { would help them cope with rising } \\
\text { temperatures (in Nawaqarua) and flooding } \\
\text { (in Koronubu-Vunibaka) } \\
\text { - Settlement relocation (Etatoko) }\end{array}$ \\
\hline
\end{tabular}

The spatial arrangement of landscape resources, stakeholders' locations within the landscape relative to these resources, and the various institutional footprints create local variability in people's access to landscape resources and ability to benefit from ecosystem service flows. The spatial arrangement of landscape resources and people's landscape activities can also contribute to climate resilience. In part, this is due to different locations having different exposure to climatic variables, and different flows of ecosystem services having varied sensitivities to climatic shocks and stressors. The institutions governing land tenure can prevent movement within landscapes as an adaptation response to the spatial variability in climate exposure; this was illustrated by the challenges faced in relocating the community to Etatoko from Wavuwavu. Socio-demographic factors also impede certain groups' capacity to use the landscape (Table 4); for example, old age preventing farmers cultivating fields far from their homestead. Ensuring land tenure, and other institutional and sociodemographic factors, do not impede flexibility in landscape management in response to climate 
stressors will be important in Fiji and Pacific Island Countries given the density of coastal populations

496 and their acute climate exposure (Lough et al., 2016; Nunn, 2009). These examples emphasise the

497 importance of integrated spatial planning within multifunctional landscapes, and, in particular,

498 place-based planning that is cognisant of where stakeholders interact with the landscape and their

499 differing capacities and institutional barriers to doing so.

500

501 A predominantly hierarchical landscape governance structure prevails within Ba resulting in

502 resources for landscape management being misaligned with actual landscape heterogeneity or

503 failing to support the range landscape users (see section 3.3.1). For example, activities that occur in

504 distant locations within the landscape impact communities locally, and local-level governance

505 systems have little capacity to exert influence on these activities. In landscapes comprising complex

506 multi-scale socio-ecological systems, such as Ba, multi-scale governance systems allow for aligning

507 management resources at appropriate scales (Biggs et al., 2012). In a global review of landscape

508 approaches Reed et al. (2017) found multi-scale governance systems were associated with successful

509 management outcomes but noted that top-down governance structures are commonplace. Effective

510 multi-scale governance might facilitate addressing other challenges to managing landscapes that

511 were identified in Ba. For example, multi-scale governance structures are associated with broader

512 participation in governance and management processes which, in turn, might enable cross-level

513 communication and the incorporation of local and place-based knowledge into landscape

514 governance (Biggs et al., 2012).

516 Communities are key groups in multi-scale governance systems; thus, cognizance of community

517 capacity to undertake landscape management is important. In contexts outside Pacific Island

518 Countries where rural communities have been effectively integrated into multi-scale governance

519 structures community-level adaptive capacity has been leveraged (Osbahr et al., 2008). However,

520 there are also documented examples of where community capacity to successfully manage natural

521 resources is limited (Blaikie, 2006; Dougill et al., 2012; Dyer et al., 2014) including in Pacific Island

522 Countries (Jupiter et al., 2017; Nunn et al., 2014). In Ba, various factors challenged community-level

523 management of landscape resources including: a lack of assets situated at the community-level for

524 utilising or monitoring landscape resources, community members' immediate needs for ecosystem

525 services being at odds with goals of long-term landscape sustainability, and local-level governance

526 systems not responding to community-level concerns regarding landscape management. These

527 factors, observed in $\mathrm{Ba}$, resonate with factors that Jupiter et al. (2017) suggest contribute to

528 successful community-led management of locally marine managed areas in Fiji. Thus, policies and 
529 projects seeking to promote landscape multifunctionality should be aware of varied groups and their

530 capacity to effect landscape management. Multi-scale governance systems should function to

531 support and enhance community capacity to manage landscape multifunctionality.

\section{Conclusions}

Challenges that stakeholders faced in managing, or deriving the benefits from, landscapes in Ba, Fiji, were identified following participatory fieldwork. Numerous landscape resources and ecosystem services support livelihoods in Ba. The landscape resources utilised, and ecosystem services valued, varies across and within communities which highlights i) complex socio-environmental interactions within the landscape, and ii) managing landscape multifunctionality is important to ensure that the diverse needs for ecosystem services of different stakeholder groups are met. The functioning of formal and informal institutions, geographic proximity to landscape resources, and physical or financial capacity shape people's ability to access landscape resources. A hierarchical governance structure prevails within Ba which is misaligned with actual landscape heterogeneity and often fails to support the diverse needs of landscape users. There was limited interaction between stakeholders across spatial levels; however, when platforms that facilitated community interaction with other stakeholders were initiated changes in landscape management ensued. Limits to community-level landscape management were observed across multiple dimensions, and, at times, community-level governance systems did not operate in accordance with community needs or goals of landscape sustainability.

As managing landscape multifunctionality becomes a more prominent goal in Pacific Island Countries awareness of the following factors will be important. Initiatives should be aware of the barriers to managing landscape multifunctionality through hierarchical governance systems and aim to establish context appropriate multi-scale governance. Such systems should facilitate communication and interaction between different stakeholders, build upon community knowledge for managing

556 landscapes, and support communities as key actors in landscape management. Consideration of the

557 spatial footprint of landscape resources, different landscape stakeholders' capacities, and

558 institutions that mediate access to landscape resources should be central to managing

559 multifunctional landscapes. Pacific Island Countries are exposed to numerous stressors which affect

560 flows of ecosystem services from landscapes; thus, management of landscape multifunctionality should also build resilience to climate stressors. 


\section{Acknowledgements}

The authors would like to thank the community members of Nawaqarua, Etatoko, and KorunubuVunibaka who participated in this research. The authors would also like to acknowledge the field staff Mereoni Matalomani and Josua Koto for their efforts with the field data collection and Camari Koto for assisting with fieldwork organisation. The authors thank the Ba Provincial Council for providing guidance and oversight for this research. This work was supported by ACIAR (grant number ASEM/2016/030). This research received ethical approval from the University of Western Australia Human Ethics office.

\section{References}

Atkinson, S.C., Jupiter, S.D., Adams, V.M., Ingram, J.C., Narayan, S., Klein, C.J., Possingham, H.P. (2016) Prioritising mangrove ecosystem services results in spatially variable management priorities. PloS one 11, e0151992.

Barbour, R.S. (2001) Checklists for improving rigour in qualitative research: a case of the tail wagging the dog? BMJ : British Medical Journal 322, 1115-1117.

Biggs, E., Bruce, E., Boruff, B., Duncan, J., Horsley, J., Pauli, N., McNeill, K., Neef, A., Ogtrop, F.V., Curnow, J. (2015) Sustainable development and the water-energy-food nexus: A perspective on livelihoods. Environmental Science \& Policy 54, 389-397.

Biggs, R., Schlüter, M., Biggs, D., Bohensky, E.L., BurnSilver, S., Cundill, G., Dakos, V., Daw, T.M., Evans, L.S., Kotschy, K. (2012) Toward principles for enhancing the resilience of ecosystem services. Annual review of environment and resources 37, 421-448.

Blaikie, P. (2006) Is small really beautiful? Community-based natural resource management in Malawi and Botswana. World development 34, 1942-1957.

Brown, P., Daigneault, A., Gawith, D., Aalbersberg, W., Comley, J., Fong, P., Morgan, F. (2014)

Evaluating Ecosystem-Based Adaptation for Disaster Risk Reduction in Fiji. Landcare Research, New Zealand Online at $\mathrm{h}$ http://www. landcareresearch. co.

nz/_data/assets/pdf_file/0004/77341/Fiji_disaster_risk_reduction. pd fi (accessed October 2014). Carpenter, S.R., Mooney, H.A., Agard, J., Capistrano, D., DeFries, R.S., Díaz, S., Dietz, T., Duraiappah, A.K., Oteng-Yeboah, A., Pereira, H.M. (2009) Science for managing ecosystem services: Beyond the Millennium Ecosystem Assessment. Proceedings of the national academy of sciences 106, 13051312.

Chambers, R. (1994) The origins and practice of participatory rural appraisal. World development 22, 953-969.

Corbett, J., (2009) Good practices in participatory mapping: a review prepared for the International Fund for Agricultural Development (IFAD). IFAD.

Dacks, R., Ticktin, T., Jupiter, S.D., Friedlander, A. (2018) Drivers of fishing at the household scale in Fiji. Ecology and Society 23.

Daigneault, A., Brown, P., Gawith, D. (2016) Dredging versus hedging: Comparing hard infrastructure to ecosystem-based adaptation to flooding. Ecological Economics 122, 25-35.

Dawson, N., Martin, A. (2015) Assessing the contribution of ecosystem services to human wellbeing: A disaggregated study in western Rwanda. Ecological Economics 117, 62-72.

Department of Energy, (2013) Fiji National Energy Policy. Government of Fiji, Suva.

Department of Town and Country Planning, (2017) Planning - Land Tenure.

DFAT, (2017) Tropical Cyclone Winston.

Di Falco, S., Bezabih, M., Yesuf, M. (2010) Seeds for livelihood: Crop biodiversity and food production in Ethiopia. Ecological Economics 69, 1695-1702. 
Di Falco, S., Chavas, J.P. (2008) Rainfall shocks, resilience, and the effects of crop biodiversity on 610 agroecosystem productivity. Land Econ 84.

611 Dougill, A.J., Stringer, L.C., Leventon, J., Riddell, M., Rueff, H., Spracklen, D.V., Butt, E. (2012) Lessons

612 from community-based payment for ecosystem service schemes: from forests to rangelands.

613 Philosophical Transactions of the Royal Society B: Biological Sciences 367, 3178-3190.

614 Dyer, J., Stringer, L.C., Dougill, A.J., Leventon, J., Nshimbi, M., Chama, F., Kafwifwi, A., Muledi, J.I., 615 Kaumbu, J.M.K., Falcao, M., Muhorro, S., Munyemba, F., Kalaba, G.M., Syampungani, S. (2014)

616 Assessing participatory practices in community-based natural resource management: Experiences in

617 community engagement from southern Africa. Journal of environmental management 137, 137-145.

618 Enfors, E. (2013) Social-ecological traps and transformations in dryland agro-ecosystems: Using

619 water system innovations to change the trajectory of development. Global Environmental Change

620 23, 51-60.

621 Estrada-Carmona, N., Hart, A.K., DeClerck, F.A.J., Harvey, C.A., Milder, J.C. (2014) Integrated

622 landscape management for agriculture, rural livelihoods, and ecosystem conservation: An

623 assessment of experience from Latin America and the Caribbean. Landscape and urban planning

624 129, 1-11.

625 Fiji Bureau of Statistics, (2018) 2017 Population and Housing Census, Suva, Fiji.

626 Foley, J.A., Ramankutty, N., Brauman, K.A., Cassidy, E.S., Gerber, J.S., Johnston, M., Mueller, N.D.,

627 O'Connell, C., Ray, D.K., West, P.C. (2011) Solutions for a cultivated planet. Nature 478, 337-342.

628 Gibbs, G.R. (2008) Analysing qualitative data. Sage.

629 Government of the Republic of Fiji, (2012) National Climate Change Policy. Secretariat of the Pacific

630 Community, Suva.

631 Harvey, C.A., Chacón, M., Donatti, C.I., Garen, E., Hannah, L., Andrade, A., Bede, L., Brown, D., Calle,

632 A., Chara, J. (2014) Climate-smart landscapes: opportunities and challenges for integrating

633 adaptation and mitigation in tropical agriculture. Conservation Letters 7, 77-90.

634

635

636

637

638

639

640

Janif, S., Nunn, P., Geraghty, P., Aalbersberg, W., Thomas, F., Camailakeba, M. (2016) Value of traditional oral narratives in building climate-change resilience: insights from rural communities in Fiji. Ecology and Society 21.

Jupiter, S.D., Epstein, G., Ban, N.C., Mangubhai, S., Fox, M., Cox, M. (2017) A Social-Ecological Systems Approach to Assessing Conservation and Fisheries Outcomes in Fijian Locally Managed Marine Areas. Society \& Natural Resources 30, 1096-1111.

Kusters, K., Buck, L., de Graaf, M., Minang, P., van Oosten, C., Zagt, R. (2017) Participatory Planning, Monitoring and Evaluation of Multi-Stakeholder Platforms in Integrated Landscape Initiatives. Environmental Management, 1-12.

Lasaqa, I.Q. (1984) The Fijian people before and after independence. Canberra; New York: Australian National University Press.

Leach, M., Mearns, R., Scoones, I. (1999) Environmental entitlements: dynamics and institutions in community-based natural resource management. World development 27, 225-247.

Lisson, S., Taylor, M., Nonga, N., Cokanasiga, K., Manueli, P., (2016) Vulnerability of livestock to climate change, in: Taylor, M., McGregor, A., Dawson, B. (Eds.), Vulnerability of Pacific Island agriculture and forestry to climate change. Pacific Community.

Lough, J., Gupta, S., Power, S., Grose, M., McGree, S., Church, J., Hoeke, R., Jones, D., Kuleshov, Y., McInnes, K., Murphy, B., Narsey, S., Wang, G., Whan, K., White, N., Wilson, L., Zhang, X., (2016) Observed and projected changes in surface climate of tropical Pacfic Islands, in: Taylor, M., McGregor, A., Dawson, B. (Eds.), Vulnerability of Pacific Island agriculture and forestry to climate change. Pacific Community.

Malmborg, K., Sinare, H., Enfors Kautsky, E., Ouedraogo, I., Gordon, L.J. (2018) Mapping regional livelihood benefits from local ecosystem services assessments in rural Sahel. PloS one 13, e0192019. McMillen, H., Ticktin, T., Friedlander, A., Jupiter, S.D., Thaman, R.R., Campbell, J., Veitayaki, J., Giambelluca, T., Nihmei, S., Rupeni, E. (2014) Small islands, valuable insights: systems of customary resource use and resilience to climate change in the Pacific. Ecology and Society 19, 44. 
660 MEA, (2005) Ecosystems and Human Well-Being: Synthesis. Millenium Ecosystem Assessment, 661 Washington DC.

662 Milder, J.C., Hart, A.K., Dobie, P., Minai, J., Zaleski, C. (2014) Integrated Landscape Initiatives for

663 African Agriculture, Development, and Conservation: A Region-Wide Assessment. World

664 development 54, 68-80.

665 Mwongera, C., Shikuku, K.M., Twyman, J., Läderach, P., Ampaire, E., Van Asten, P., Twomlow, S.,

666 Winowiecki, L.A. (2017) Climate smart agriculture rapid appraisal (CSA-RA): A tool for prioritizing

667 context-specific climate smart agriculture technologies. Agricultural Systems 151, 192-203.

668 Neef, A., Benge, L., Boruff, B., Pauli, N., Weber, E., Varea, R. (2018) Climate adaptation strategies in

669 Fiji: The role of social norms and cultural values. World development 107, 125-137.

670 Nunn, P.D. (2009) Responding to the challenges of climate change in the Pacific Islands:

671 management and technological imperatives. Climate Research 40, 211-231.

672 Nunn, P.D., Aalbersberg, W., Lata, S., Gwilliam, M. (2014) Beyond the core: community governance

673 for climate-change adaptation in peripheral parts of Pacific Island Countries. Regional Environmental

674 Change 14, 221-235.

675 O'Farrell, P.J., Anderson, P.M. (2010) Sustainable multifunctional landscapes: a review to

676 implementation. Current Opinion in Environmental Sustainability 2, 59-65.

677 Osbahr, H., Twyman, C., Adger, W.N., Thomas, D.S. (2008) Effective livelihood adaptation to climate

678 change disturbance: scale dimensions of practice in Mozambique. Geoforum 39, 1951-1964.

679 Pacific R2R - Ridge to Reef, (2018) Pacific-r2r.

680 Potschin, M., Haines-Young, R. (2013) Landscapes, sustainability and the place-based analysis of

681 ecosystem services. Landscape Ecology 28, 1053-1065.

682 Rasmussen, L.V., Mertz, O., Christensen, A.E., Danielsen, F., Dawson, N., Xaydongvanh, P. (2016) A

683 combination of methods needed to assess the actual use of provisioning ecosystem services.

684 Ecosystem Services 17, 75-86.

685 Reed, J., van Vianen, J., Barlow, J., Sunderland, T. (2017) Have integrated landscape approaches

686

687

688

689

690

691

692

693

694

695

696

697

698

699

700

701

702

703

704

705

706

707

708

709

710 reconciled societal and environmental issues in the tropics? Land Use Policy 63, 481-492.

Reed, M.S., Graves, A., Dandy, N., Posthumus, H., Hubacek, K., Morris, J., Prell, C., Quinn, C.H., Stringer, L.C. (2009) Who's in and why? A typology of stakeholder analysis methods for natural resource management. Journal of environmental management 90, 1933-1949.

Sano, Y. (2008) The role of social capital in a common pool resource system in coastal areas: A case study of community-based coastal resource management in Fiji.

Sayer, J., Sunderland, T., Ghazoul, J., Pfund, J.-L., Sheil, D., Meijaard, E., Venter, M., Boedhihartono, A.K., Day, M., Garcia, C. (2013) Ten principles for a landscape approach to reconciling agriculture, conservation, and other competing land uses. Proceedings of the national academy of sciences 110 , 8349-8356.

Sayer, J.A., Margules, C., Boedhihartono, A.K., Sunderland, T., Langston, J.D., Reed, J., Riggs, R., Buck, L.E., Campbell, B.M., Kusters, K., Elliott, C., Minang, P.A., Dale, A., Purnomo, H., Stevenson, J.R., Gunarso, P., Purnomo, A. (2016) Measuring the effectiveness of landscape approaches to conservation and development. Sustainability Science, 1-12.

Scherr, S.J., McNeely, J.A. (2008) Biodiversity conservation and agricultural sustainability: towards a new paradigm of 'ecoagriculture' landscapes. Philosophical Transactions of the Royal Society B: Biological Sciences 363, 477-494.

Scherr, S.J., Shames, S., Friedman, R. (2012) From climate-smart agriculture to climate-smart landscapes. Agriculture \& Food Security $1,1$.

Schreckenberg, K., Torres-Vitolas, C., Willcock, S., Shackleton, C., Harvey, C., Kafumbata, D., (2016)

Participatory Data Collection for Ecosystem Services Research, ESPA Working Paper Series.

Sibhatu, K.T., Krishna, V.V., Qaim, M. (2015) Production diversity and dietary diversity in smallholder farm households. Proceedings of the national academy of sciences 112, 10657-10662.

Sinare, H., Gordon, L.J., Enfors Kautsky, E. (2016) Assessment of ecosystem services and benefits in village landscapes - A case study from Burkina Faso. Ecosystem Services 21, 141-152. 
Sisifia, A., Taylor, M., McGregor, A., Fink, A., Dawson, B., (2016) Pacific Communities, Agriculture, and Climate Change, in: Taylor, M., McGregor, A., Dawson, B. (Eds.), Vulnerability of Pacific Island agriculture and forestry to climate change. Pacific Community. SPREP, (2018) PEBACC. Taylor, M., Lal, P., Solofa, D., Sukal, A., Atumurirava, F., Manley, M., Nonga, N., Groom, S., Starz, C., (2016) Agriculture and climate change: an overview, in: Taylor, M., McGregor, A., Dawson, B. (Eds.), Vulnerability of Pacific Island agriculture and forestry to climate change. Pacific Community. Termorshuizen, J.W., Opdam, P. (2009) Landscape services as a bridge between landscape ecology and sustainable development. Landscape Ecology 24, 1037-1052.

Thornton, P.K., Herrero, M. (2015) Adapting to climate change in the mixed crop and livestock farming systems in sub-Saharan Africa. Nature Clim. Change 5, 830-836.

Tompkins, E., Adger, W.N. (2004) Does adaptive management of natural resources enhance resilience to climate change? Ecology and Society 9.

Vunisea, A. (2016) The participation of women in fishing activities in Fiji. SPC Women in Fisheries Information Bulletin 7.

Wairiu, M. (2017) Land degradation and sustainable land management practices in Pacific Island Countries. Regional Environmental Change 17, 1053-1064.

Walter, M.A. (1978) Analysis of Fijian traditional social organization: the confusion of local and descent grouping. Ethnology, 351-366.

Zanzanaini, C., Trần, B.T., Singh, C., Hart, A., Milder, J., DeClerck, F. (2017) Integrated landscape initiatives for agriculture, livelihoods and ecosystem conservation: An assessment of experiences from South and Southeast Asia. Landscape and urban planning 165, 11-21.

\section{Fig. 1 Land cover map of the Ba Catchment. The land cover data were obtained from the Ministry} of Agriculture, Fiji.

Fig. 2 Average monthly precipitation and minimum and maximum temperatures (climate data from Worldclim).

Fig. 3 Schematic of indigenous Fijian social groupings adapted from Walter (1978), Sano (2008) and Lasaqa (1984). 


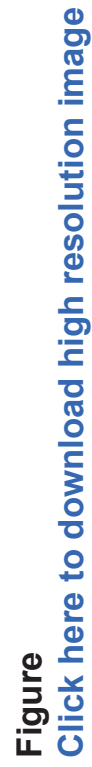

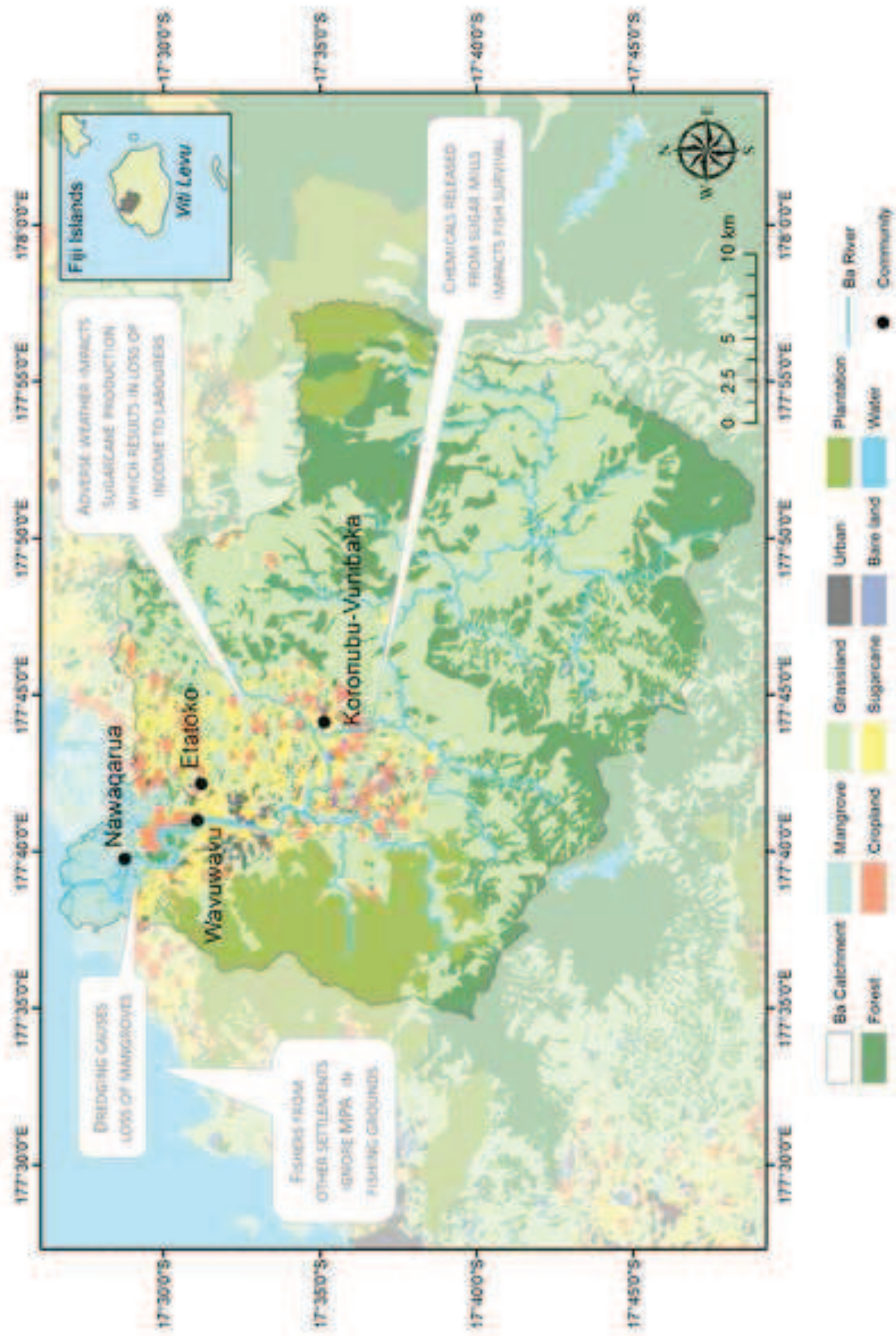




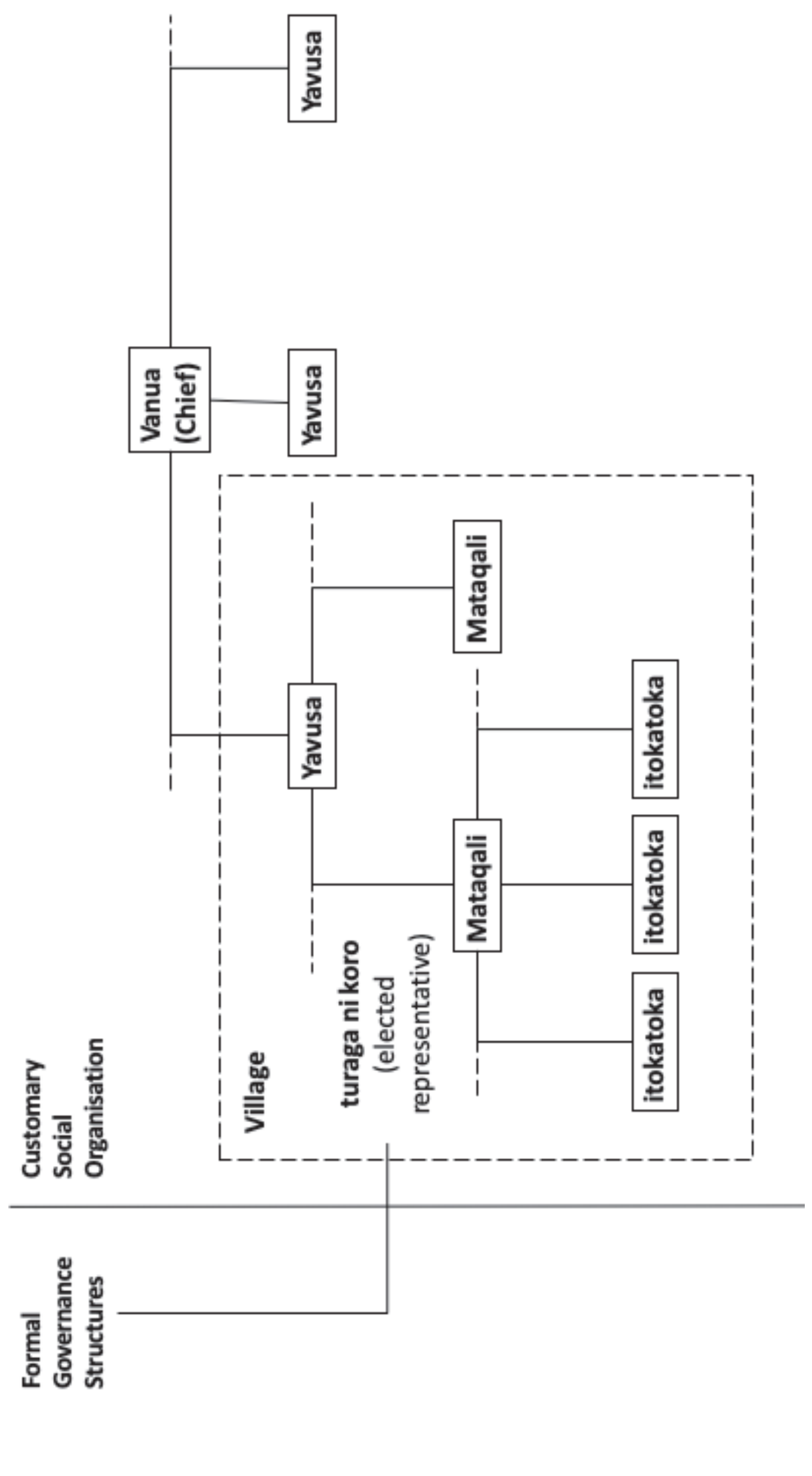




\section{${ }^{*}$ Declaration of Interest Statement}

\section{Declaration of interests}

$\bigotimes$ The authors declare that they have no known competing financial interests or personal relationships that could have appeared to influence the work reported in this paper.

$\square$ The authors declare the following financial interests/personal relationships which may be considered as potential competing interests:

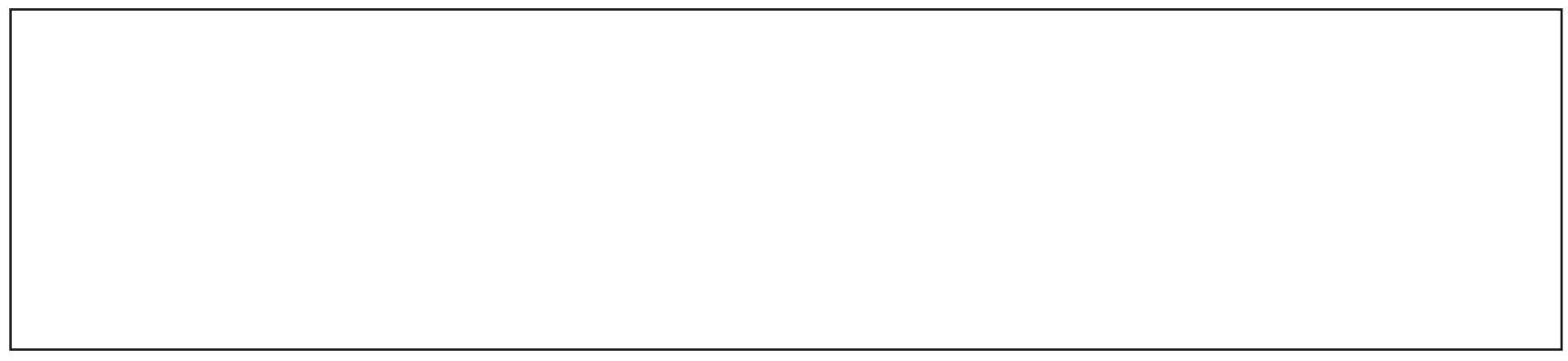

